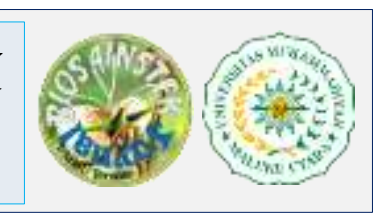

\title{
Pengetahuan Perilaku Hidup Bersih Dan Sehat Serta Pencegahan Covid-19 Oleh Pemuda Di Kelurahan Benteng Kota Ambon
}

\author{
Yonette Maya Tupamahu ${ }^{\circledR}$ dan Salomi Jacomina Hehanussa ${ }^{1}$ \\ 1 Staf Pengajar Fakultas Ekonomi dan Bisnis Universitas Kristen Indonesia Maluku. Ambon-Indonesia, \\ Email :ymtup@yahoo.co.id dan hehanussasj.ukim@gmail.com

\footnotetext{
Korespondensi : Yonette Maya Tupamahu, Universitas Kristen Indonesia Maluku. Ambon-Indonesia, Email : ymtup@yahoo.co.id
}

\begin{abstract}
ABSTRAK
Virus SARS-Cov-2 atau virus Corona menyerang sistem pernapasan manusia dan menimbulkan gangguan ringan sampai berat, bahkan kematian. Penularannya antar manusia melalui cipratan liur (droplet) yang dikeluarkan seseorang dari mulut atau hidung ketika bersin, batuk, bahkan saat berbicara. Perilaku Hidup Bersih dan Sehat (PHBS) dapat diterapkan oleh masyarakat untuk memutus rantai penyebaran virus Corona, termasuk di Kelurahan Benteng Kota Ambon. Permasalahan yang dihadapi saat ini adalah kurangnya pemahaman Covid-19, dimana masih ada warga yang beranggapan bahwa Covid-19 itu tidak ada. Berdasarkan masalah dan solusi yang ditawarkan kepada mitra, maka kegiatan yang telah dilakukan adalah: (1) Ceramah Perilaku Hidup Bersih dan Sehat, (2) Ceramah Pencegahan Covid-19. Hasil kegiatan menunjukkan adanya peningkatan pengetahuan pemuda sebelum dan sesudah mendapatkan ceramah. Luaran kegiatan ini juga telah dipublikasikan pada media cetak dan elektronik http://beritakotaambon.com/mahasiswa-kkn-ukim-berkontribusi-putuskan-covid-19/, dan video kegiatan telah diupload di saluran Youtube https://www.youtube.com/watch?v=Buq6nISpXYk.
\end{abstract}

Keyword: Clean and healthy lifestyle, prevention of covid-19

\section{PENDAHULUAN}

Wabah pneumonia yang disebabkan virus Corona baru terjadi di Wuhan, Provinsi Hubei, pada Desember 2019 dan menyebar cepat ke seluruh Cina dan dunia. Virus SARS-Cov-2 atau virus Corona menyerang sistem pernapasan manusia dan menimbulkan gangguan ringan sampai berat, bahkan kematian (Satgas Penanganan Covid-19, 2020).

Kasus pertama positif Covid-19 di Indonesia diumumkan pada tanggal 2 Maret 2020 yaitu 2 orang WNI yang terinfeksi setelah berinteraksi dengan WNA pengidap Covid-19 asal Jepang. Hingga 30 Desember 2020, persentase penyebaran virus Corona di Indonesia adalah 735.124 terkonfirmasi, 603.741 sembuh $(82,12 \%$ dari terkonfirmasi) dan 21.944 meninggal (2,9\% dari terkonfirmasi), dan khusus di Provinsi Maluku sebanyak 5693 kasus terkonfirmasi.

Virus Corona dapat menular antar manusia melalui cipratan liur (droplet) yang dikeluarkan seseorang dari mulut atau hidung ketika bersin, batuk, bahkan saat berbicara. Droplet dapat jatuh dan menempel pada benda-benda sekitar, sehingga tangan kita berpotensi menjadi jalur transmisi ketika mememgang benda-benda tersebut. Kelemahan virus ini adalah dapat mati jika tempat hidupnya dibersihkan dengan sabun (Satgas Penanganan Covid-19, 2020).

Perilaku Hidup Bersih dan Sehat (PHBS) dapat diterapkan oleh masyarakat untuk memutus rantai penyebaran virus Corona. PHBS adalah sekumpulan perilaku yang dipraktekkan atas dasar kesadaran sebagai hasil pembelajaran, yang menjadikan seseorang, keluarga, kelompok atau masyarakat mampu menolong dirinya sendiri (mandiri) di bidang kesehatan dan berperan aktif dalam mewujudkan kesehatan masyarakat (Kementerian Kesehatan RI, 2011). PHBS harus dipraktikkan secara terus-menerus agar menjadi suatu pola kebiasaan (Kementerian Sosial RI, 2020).

Pelaksanaan pembinaan PHBS dilakukan di berbagai tatanan seperti rumah tangga, institusi pendidikan, tempat kerja, tempat umum, serta fasilitas kesehatan (Kementerian Kesehatan RI, 2011). 
Dalam kaitan adanya pandemi Covid-19, maka sangatlah penting bagi masyarakat untuk melakukan PHBS dalam kehidupan sehari-hari, yaitu rajin mencuci tangan dengan menggunakan air bersih. Hal ini sejalan dengan strategi pencegahan Covid-19 yang difokuskan pada peningkatan kepatuhan 3M, yakni Memakai Masker, Menjaga Jarak, dan Mencuci Tangan. Hal ini penting sebab banyaknya orang yang terkonfirmasi positif Covid-19 tanpa gejala tetapi berbahaya dan dapat menyebabkan kematian bagi orang disekitarnya (Satgas Penanganan Covid-19, 2020).

Dampak pandemi Covid-19 saat ini memicu kekhawatiran akan krisis ekonomi dan resesi yang akan datang. Jarak sosial, isolasi diri, dan pembatasan perjalanan telah menyebabkan berkurangnya tenaga kerja di semua sektor ekonomi dan menyebabkan banyak pekerjaan hilang. Sekolah-sekolah telah ditutup, dan kebutuhan akan komoditas serta produk manufaktur menurun. Sebaliknya, kebutuhan perbekalan kesehatan meningkat secara signifikan. Sektor makanan juga menghadapi peningkatan permintaan karena panik membeli dan menimbun produk makanan. (Nicola, et. al., 2020). Kondisi ini dapat ditemui di secara global termasuk di Kelurahan Benteng.

Kondisi Covid-19 telah mengganggu rantai pasok barang, dan kerugian (Haleem, et.al, 2020). Bahwa dampak aspek kesehatan yaitu tantangan dalam diagnosis, karantina dan pengobatan kasus yang diduga atau terkonfirmasi; beban tinggi dari berfungsinya sistem medis yang ada; penderita penyakit lain dan masalah kesehatan semakin terabaikan, beban berlebihan pada dokter dan profesional perawatan kesehatan lainnya, yang berisiko sangat tinggi; toko medis yang kelebihan muatan. persyaratan perlindungan yang tinggi; gangguan rantai pasokan medis.

Dampak Covid-19 secara sosial antara lain pembatalan atau penundaan olahraga dan turnamen berskala besar; menghindari perjalanan nasional dan internasional dan pembatalan layanan; gangguan perayaan budaya, agama dan acara perayaan; stres yang berlebihan di antara populasi; jarak sosial dengan teman sebaya dan anggota keluarga; penutupan hotel, restoran dan tempat ibadah; penutupan tempat-tempat hiburan (Haleem, et.al, 2020). Dalam rangka pencegahan penyebaran Covid-19, penting untuk menerapkan Perilaku Hidup Bersih dan Sehat.

\section{PERMASALAHAN PRIORITAS MITRA}

KKN-PPM Angkatan ke-50 Kelompok 4 dan 5 dilaksanakan di wilayah tempat tinggal mahasiswa yaitu Kelurahan Benteng Kota Ambon. Permasalahan yang dihadapi adalah bahwa kurangnya pemahaman Covid-19, dimana masih ada warga yang beranggapan bahwa Covid-19 itu tidak ada. Pemahaman ini akan berdampak pada makin meningkatnya pasien terdampak Covid-19. Hal ini tentunya sangat beresiko tinggi terhadap penyebaran Covid-19 jika masyarakat tidak lagi memperhatikan protokol kesehatan, yakni memakai masker, mencuci tangan dan menjaga jarak.

\section{SOLUSI PERMASALAHAN}

Berdasarkan permasalahan tersebut, maka solusi yang ditawarkan adalah :

1. Memberikan ceramah tentang Perilaku Hidup Bersih dan Sehat (PHBS).

2. Memberikan ceramah tentang Pencegahan Covid -19 .

Pemberian ceramah dimaksudkan untuk meningkatkan pengetahuan peserta ceramah. Tingkat pengetahuan memiliki hubungan positif dan nyata dengan praktik PHBS pada keluarga atau rumah tangga, siswa, lansia, serta masyarakat (Kustantya dan Anwar, 2013; Sulastri, dkk., 2013; Corolina, dkk., 2016; Chandra, dkk, 2017; Widyastuti dan Hilal, 2018). Berperilaku hidup bersih dan sehat meningkatkan produktifitas dan kualitas hidup serta ketahanan dari serangan berbagai penyakit (Kementerian Sosial, 2020).

Sasaran ceramah ini adalah pemuda di Kelurahan Benteng, hal ini disebabkan Covid-19 dapat menyerang siapa saja tanpa terkecuali, termasuk anak muda. Kelompok pemuda memiliki imunitas yang lebih baik sehingga mungkin dapat terpapar tanpa menunjukkan gejala atau asimtomatik (Satgas Penanganan Covid-19, 2020).

\section{METODE PELAKSANAAN}

Tahap-tahap pelaksanaan kegiatan KKN-PPM adalah sebagai berikut:

\subsection{Tahap Persiapan.}

1. Instruktur melakukan orientasi lapangan dan konsolidasi dengan pihak mitra, dimana tim langsung bertemu dengan Ketua Majelis Jemaat GPM Nehemia dan melakukan observasi lanjutan untuk menentukan materi dan kajian 
2. Para instruktur bersama mahasiswa mengadakan pertemuan untuk mempersiapkan konsep kegiatan, materi, pemateri atau fasilitator ceramah.

3. Mahasiswa KKN-PPM menyiapkan alat dan bahan ceramah.

\subsection{Tahap Pelaksanaan.}

1. Ceramah tentang bahaya Covid-19 dan PHBS dilakukan pada waktu bersamaan, dan ditujukan bagi pemuda khususnya yang berada di wilayah pelayanan Gereja Protestan Maluku Jemaat Nehemia Benteng. Pemateri adalah mahasiswa KKN-PPM khususnya Program Studi Keperawatan.

2. Sebelum kegiatan, mahasiswa membagikan lembaran soal pre-test dalam bentuk pilihan berganda sebanyak 15 butir soal, kemudian pemuda diberikan ceramah tentang bahaya Covid-19 dan PHBS. Setelah itu mahasiswa membagikan lembaran soal post-test, sehingga diketahui adanya peningkatan pengetahuan pemuda sebelum dan sesudah mendapat ceramah.

3. Setelah kegiatan, mahasiswa menyerahkan 1 unit tempat cuci tangan sistim injak, 1 unit tempat handsanitiser sistim injak, serta pembagian masker kain bagi peserta ceramah.

\section{HASIL DAN LUARAN YANG DICAPAI}

\subsection{Ceramah Perilaku Hidup Bersih dan Sehat (PHBS)}

Ceramah PHBS dilaksanakan di Gereja Sumber Kasih Jemaat GPM Nehemia Benteng, pada hari Rabu, 28 Oktober 2020. Kegiatan ini dimulai pada pukul 20.00-20.30 WIT dan diikuti oleh seorang kateket dan para pemuda yang sedang mengikuti pendidikan katekisasi. Kegiatan diawali dengan peserta menjawab soal pre-test, dilanjutkan ceramah tentang apa saja PHBS yang terdapat dalam masyarakat. Sesudah ceramah dilakukan sesi tanya-jawab dan diakhiri peserta menjawab soal post-test. Post-test dimaksudkan untuk mengukur ada tidaknya peningkatan pengetahuan peserta. Luaran yang dicapai dari pelaksanaan kegiatan ini adalah adanya peningkatan pengetahuan tentang PHBS oleh semua peserta, hal ini menunjukkan bahwa kegiatan ini sangat bermanfaat.

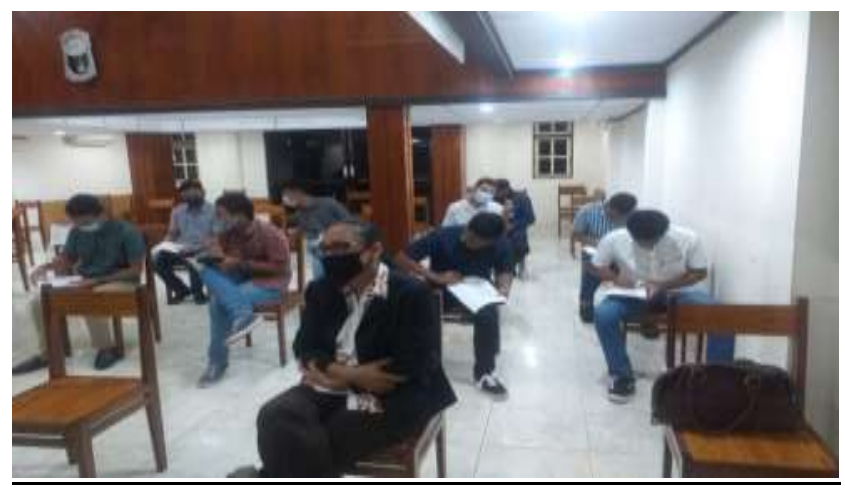

Gambar 1. Sebelum Ceramah Dilaksanakan Peserta Menjawab Soal Pre-Test dan Sesudah Ceramah Menjawab Soal Post-Test

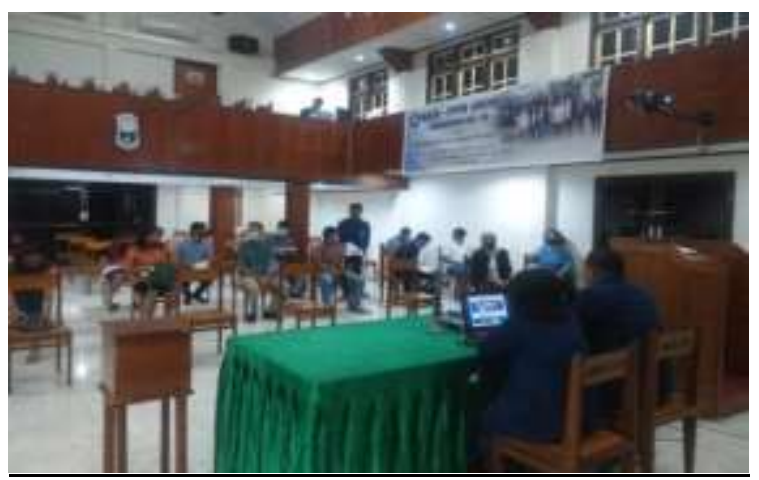

Gambar 2. Kegiatan Ceramah Perilaku Hidup Bersih dan Sehat (PHBS) oleh Mahasiswa

\subsection{Ceramah Pencegahan Covid-19}

Ceramah Pencegahan Covid-19 dilaksanakan lokasi yang sama pada pukul 20.30 - 21.00 WIT. Sebelum ceramah dimulai, peserta ceramah diminta untuk menjawab soal pre-test, dan dilanjutkan ceramah berisi informasi terkini terkait perubahan perilaku dalam upaya pencegahan Covid-19, dimana ada empat topik utama yaitu: a) Kenali Dirimu, menjelaskan orang-orang dengan resiko tinggi; b) Kenali Musuhmu, menjelaskan apa itu virus Corona dan kelemahannya; c) Kenali Medan Perangmu, menjelaskan kewaspadaan di area atau tempat kita berada; dan d) Menang Melawan Covid-19, menjelaskan tentang 3M, cara memakai dan membuang masker sekali pakai dengan benar, cara mencuci masker kain dengan benar, menjaga jarak dan menghindari kerumunan, mencuci tangan dengan sabun menurut WHO, serta menjaga daya tahan tubuh dan mental. Sesudah ceramah dilakukan sesi tanya-jawab terkait materi ceramah, selanjutnya peserta menjawab soal post-test. Luaran yang dicapai dari kegiatan ini menunjukkan adanya perbedaan peningkatan pengetahuan peserta sebelum dan setelah mendapatkan ceramah. Tentunya diharapkan bahwa peserta ceramah dapat berperan sebagai agen perubahan perilaku, dengan menyampaikan informasi yang diperolehnya kepada orang lain. 


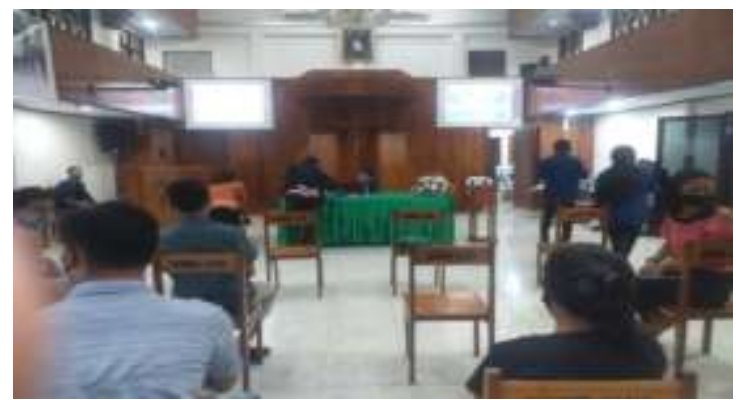

Gambar 3. Kegiatan Ceramah Pencegahan Covid-19 oleh Mahasiswa

\subsection{Penyerahan Tempat Cuci Tangan, Tempat Handsanitiser Sistem Injak, dan Masker Kain}

Kegiatan lainnya yang dilakukan oleh mahasiswa KKN-PPM Angkatan ke-50 Kelompok 4 dan 5 adalah pembuatan tempat cuci tangan dan tempat handsanitiser sistem injak, serta pengadaan masker kain. Pembuatan tempat cuci tangan dan handsanitiser sistem injak dengan pertimbangan bahwa penularan Covid-19 masih dapat terjadi bilamana tempat cuci tangan dipakai secara bersama-sama. Sedangkan masker kain tidaklah berbahan tipis seperti masker scuba dan buff. Menurut Kementerian Kesehatan RI (2020), masker scuba dan buff tidak memenuhi syarat karena jika masker tersebut ditarik pori-porinya akan terbuka lebar. Masker kain dapat dipakai berulang-ulang dengan menerapkan cara mencuci masker kain yang benar. Setelah kegiatan ceramah maka dilakukan penyerahan tempat cuci tangan dan handsanitiser sistem injak kepada Gereja Sumber Kasih Jemaat GPM Nehemia Benteng, serta pembagian masker kain bagi seluruh peserta.

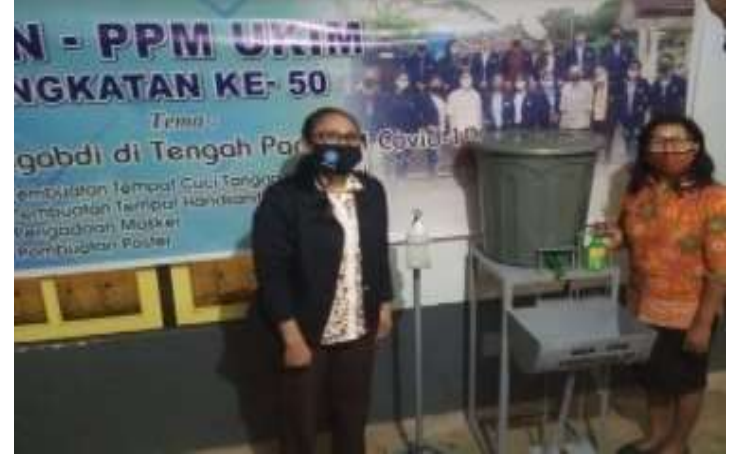

Gambar 3. Penyerahan Tempat Cuci Tangan dan Tempat Handsanitiser Sistem Injak

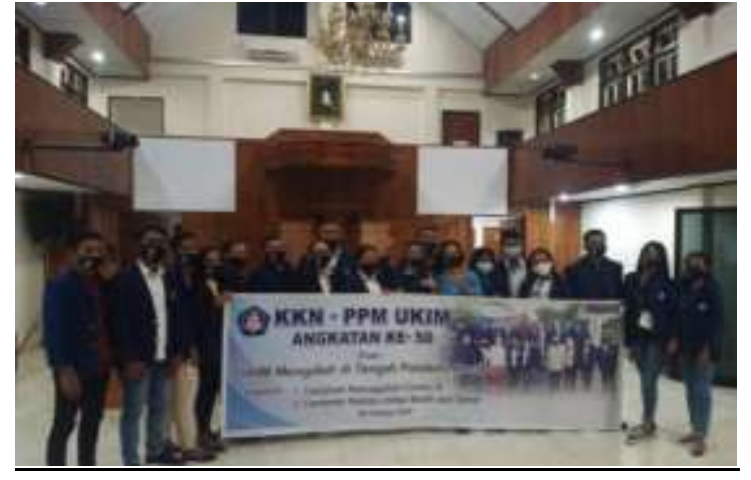

Gambar 4. Foto Bersama Para Instruktur dan Mahasiswa KKN Kelompok 4 dan 5

\section{PENUTUP}

Demikianlah kegiatan KKN-PPM Angkatan ke-50 Tahun Akademik 2020/2021 yang dilaksanakan di Kelurahan Benteng oleh Kelompok 4 dan 5. Sebagai luaran kegiatan ini, kami telah menerbitkan artikel di media cetak Harian Berita Kota secara cetak dan elektronik pada tanggal 10 November 2020, dimana artikel elektroniknya dapat dilihat pada http://beritakotaambon.com/mahasiswa-kkn-ukim-berkontribusi-putuskan-covid-19/, dan video kegiatan telah diupload di saluran Youtube https://www.youtube.com/watch?v=Buq6nISpXYk. Diharapkan informasi ini dapat diteruskan kepada orang lain untuk pencegahan penyebaran Covid-19.

\section{UCAPAN TERIMA KASIH}

Ucapan terima kasih kepada Rektor Universitas Kristen Indonesia Maluku, Lembaga Pengabdian Masyarakat UKIM, serta mitra atas bantuan dan partisipasinya sehingga kegiatan KKN-PPM Angkatan ke-50 Kelompok 4 dan 5 di Kelurahan Benteng dapat berjalan dengan baik.

\section{DAFTAR PUSTAKA}

Carolina, P., M. Carolina, R. M. Lestari, 2016. Hubungan Tingkat Pengetahuan dan Sumber Informasi Dengan Penerapan Perilaku Hidup Bersih dan Sehat (PHBS) Pada Keluarga di Wilayah Kerja Pustu Pahandut Seberang Kota Palangka Raya Tahun 2016, Jurnal Ilmiah Bidang Pengelolaan Sumberdaya Alam dan Lingkungan, 12 (3): 330-337 
Chandra, A. Fauzan, M. F. Aquarista, 2017. Hubungan Antara Pengetahuan dan Sikap Dengan Perilaku Hidup Bersih dan Sehat (PHBS) Pada Siswa Sekolah Dasar (SD) di Kecamatan Cerbon Tahun 2016, Jurnal Kesehatan Masyarakat Khatulistiwa, 4 (3): 201-205

Haleem, Abid, Mohd Javaid, Raju Vaishya, 2020. Effects of COVID-19 pandemic in daily life. Current Medicine Research and Practice, https://doi.org/10.1016/j.cmrp.2020.03.011

Nicola, Maria, ZaidAlsafi, Catrin Sohrabi, Ahmed Kerwan, Ahmed Al-Jabir, Christos Iosifidis, Maliha Agha, Riaz Agha, 2020. The socio-economic implications of the coronavirus pandemic (COVID-19): A review. International Journal of Surgery Vol 78, June 2020, pages 185-193

Kementerian Kesehatan RI, 2011. Pedoman Pembinaan Perilaku Hidup Bersih dan Sehat (PHBS).

, 2020. Kemenkes Sarankan 3 Jenis Masker Untuk Dipakai, https://www.kemkes.go.id /article/view/20092200001/kemenkes-sarankan-3-jenis-masker-untuk-dipakai.html

Kementerian Sosial RI, 2020. Perilaku Hidup Bersih dan Sehat (PHBS): Penguatan Kapabilitas Anak dan Keluarga, Direktorat Rehabilitasi Sosial Anak - Direktorat Jendral Rehabilitasi Sosial, Jakarta.

Kustantya, N. dan M. S. Anwar, 2013. Hubungan Tingkat Pengetahuan Dengan Perilaku Hidup Bersih dan Sehat (PHBS) Pada Lansia, Jurnal Keperawatan, 4(1): 29-35

Satgas Penanganan Covid-19, 2020. Pedoman Perubahan Perilaku Penanganan Covid-19, Oktober 2020, BNPB, Jakarta.

2020. Satgas Covid-19: Taget Penanganan Harus Capai 100 Persen Kesembuhan, https://covid19.go.id/regulasi/satgas-covid-19-target-penanganan-harus-capai-100persen-kesembuhan, tanggal 31 Desember 2020

Sulastri, K., I. N. Purna, dan I. N. Suyasa, 2013. Hubungan Tingkat Pengetahuan Dengan Perilaku Anak Sekolah Tentang Hidup Bersih dan Sehat di Sekolah Dasar Negeri Wilayah Puskesmas Selemadeg Timur II, Jurnal Kesehatan Lingkungan, 4(1): 99-106

Widyastuti, K. dan N. Hilal, 2018. Hubungan Tingkat Pengetahuan Dengan Perilaku Hidup Bersih dan Sehat (PHBS) di Desa Banjarsari Kulon Kabupaten Banyumas Tahun 2017, Buletin Kesehatan Lingkungan Masyarakat, 37 (2): 192-198 